\title{
Heat Transfer in Helical Coil Heat Exchanger
}

\author{
Uwem Ekwere Inyang*, Iniubong James Uwa \\ Department of Chemical and Petroleum Engineering, Faculty of Engineering, University of Uyo, Uyo, Nigeria \\ Email: *uweminyang@uniuyo.edu.ng
}

How to cite this paper: Inyang, U.E. and Uwa, I.J. (2022) Heat Transfer in Helical Coil Heat Exchanger. Advances in Chemical Engineering and Science, 12, 26-39. https://doi.org/10.4236/aces.2022.121003

Received: November 13, 2021

Accepted: January 4, 2022

Published: January 7, 2022

Copyright (c) 2022 by author(s) and Scientific Research Publishing Inc. This work is licensed under the Creative Commons Attribution International License (CC BY 4.0).

http://creativecommons.org/licenses/by/4.0/

\section{(c) (i) Open Access}

\begin{abstract}
The research paper tends to review the effectiveness of helical coil in heat exchangers (HCHE). Heat exchanger is a device used in transferring thermal energy between two or more fluids or solid interfaces and a fluid, in solid particulates and a fluid at different temperatures and thermal contact. The author has concisely discussed the helical coil in heat exchanger at different shapes and conditions and compared the HCHE with straight tubes heat exchangers, and the factors affecting the performance and effectiveness of the helical coil heat exchanger such as the curvature ratio, and other heat exchangers. The author demonstrated that the HCHE provided more excellent heat transfer performance and effectiveness than straight tubes and other heat exchangers because of secondary flow development inside the helical tube, and heat transfer coefficient increased with an increase in the curvature ratio of HCHE for the same flow rates. The secondary flow and mass flow rates, advantages and disadvantages have also been reviewed. The authors back their findings with available theories. Suitable fluid should be searched for high efficiency in the helical coil.
\end{abstract}

\section{Keywords}

Helical Coil, Heat Transfer, Heat Exchanger, Boundary Conditions, Temperature

\section{Introduction}

A heat exchanger is a device that is used to transfer thermal energy (enthalpy) between two or more fluids, between a solid surface and a fluid, or between solid particulates and a fluid, at different temperatures and in thermal contact [1] [2]. In global industrialization, efforts have been made to increase heat transfer rate, minimize the size of heat exchangers, and to improve the effectiveness of heat exchangers. Helical coil heat exchanger (HCHE) offer distinct advantages, such as improved thermal efficiency, compactness, easy maintenance and lower in- 
stalled cost [3]. Heat transfer in helical coils has been studied and researched, because of the fluid dynamics inside the pipes of a helical coil heat exchange [4]. Helically coiled tube heat exchangers are the most widely used from the family of coiled heat exchangers [5].

Helical coil configuration is very effective for heat exchangers due to their excellent heat transfer performance and compact size as compared to straight tube heat exchangers [6] [7] [8] [9] [10]. The application of curved tubes in laminar flow heat exchange is highly beneficial than straight tubes [11]. Heat transfer rate of helical tube is significantly higher because of the secondary flow caused by the centrifugal force [12] [13]. The development of secondary flows (Dean vortices) in these helical tubes enhances the radial mixing, while keeping a low axial back-mixing behaviour thus increases heat and mass transfer and leads to narrower residence time distributions [14].

According to [15], the secondary flows constitute two sets of distinct re-circulating vortices along the diameter of tube as shown in Figure 1. This secondary flow has the ability for heat transfer enhancement due to mixing of fluid in the tube [4]. [16] reported that the improvement in heat transfer rate in curve tube tubes was due to the centrifugal force which pushed the fluid particles toward the core region that produced a secondary flow field. The intensity of secondary flow [17] [18] developed in the tube is the function of tube diameter ( $d$ ) and coil diameter $(D)$. This increase in intensity of secondary flow allows proper mixing of the fluid, which enhances heat transfer coefficient for the same flow rate. [19] reported the increase in tube and coil diameter, reduced the secondary flow developed and in turn reduced heat transfer coefficient.

\subsection{Heat Transfer Characteristics in Coiled Tubes}

Helically coiled tubes are useful for various industrial processes such as combustion systems, heat exchangers, solar collectors, and distillation processes because of their simple and effective means of enhancement in heat and mass transfer

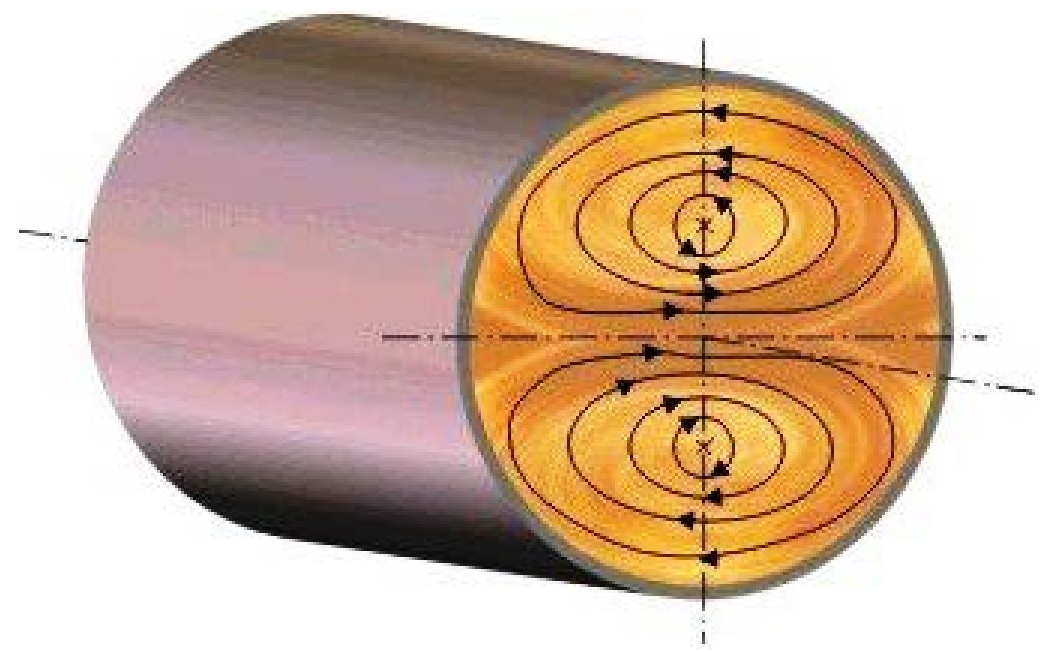

Figure 1. Secondary flow in a coiled tube. Source: [20]. 
[21]. According to [22], the heat transfer characteristics in coiled tubes are determined by the peculiarities of the axial velocity distribution and of secondary flow as shown in Figure 1. Secondary flow arises in the form of a pair of symmetrical vortices in the cross-section along the tube axis, the fluid trajectory is in the form of a double coil. Hence, the mean heat transfer coefficient for laminar flow in coiled tubes is given by the Equation (1).

$$
\overline{N u}=0.06 \operatorname{Re}^{0.7} \operatorname{Pr}^{0.43}\left(\frac{\operatorname{Pr}_{f}}{\operatorname{Pr}_{w}}\right)^{0.25}\left(d / D_{\text {coil }}\right)^{0.18}
$$

where $P r$ is Prandtl number $P r_{f}$ of fluid and $P r_{w}$ of water, $R e$ is Reynolds number, $d$ is the tube diameter, $D_{\text {coil }}$ is the coil diameter, $N u=\alpha L / \lambda$ is Nusselt number which is the dimensionless parameter characterizing convective heat transfer where $\alpha$ is convective heat transfer coefficient, $L$ is representative dimension (e.g., diameter for pipes), and $\lambda$ is the thermal conductivity of the fluid. Nusselt number is a measure of the ratio between heat transfer by convection $(\alpha)$ and heat transfer by conduction alone $(\lambda / L)$. Figure 2 shows the necessary parameters of shell and tube HCHE, where $P_{c}$ is the coil pitch.

For turbulent flow in coiled tubes, the heat transfer coefficient distribution around the tube perimeter is essentially non-uniform. The non-uniformity is caused by the non-homogeneity of the flow velocity and temperature distributions which can cause heat transfer from the inner to the outer generatrix. [22] showed that the mean Nusselt number for a coiled tube is greater than that of straight tube and the heat transfer coefficient also increased with a decrease in the ratio of coil diameter to tube diameter $\left(D_{\text {coil }} / d\right)$. [24] reported that coiled tubes have better heat transfer coefficient and residence time distributions and were therefore used in compact heat exchangers. Also, the application of flow and helical coils in heat exchangers and reactors are due to higher heat and mass transfer coefficients with narrow residence time distributions and compact structure [25].

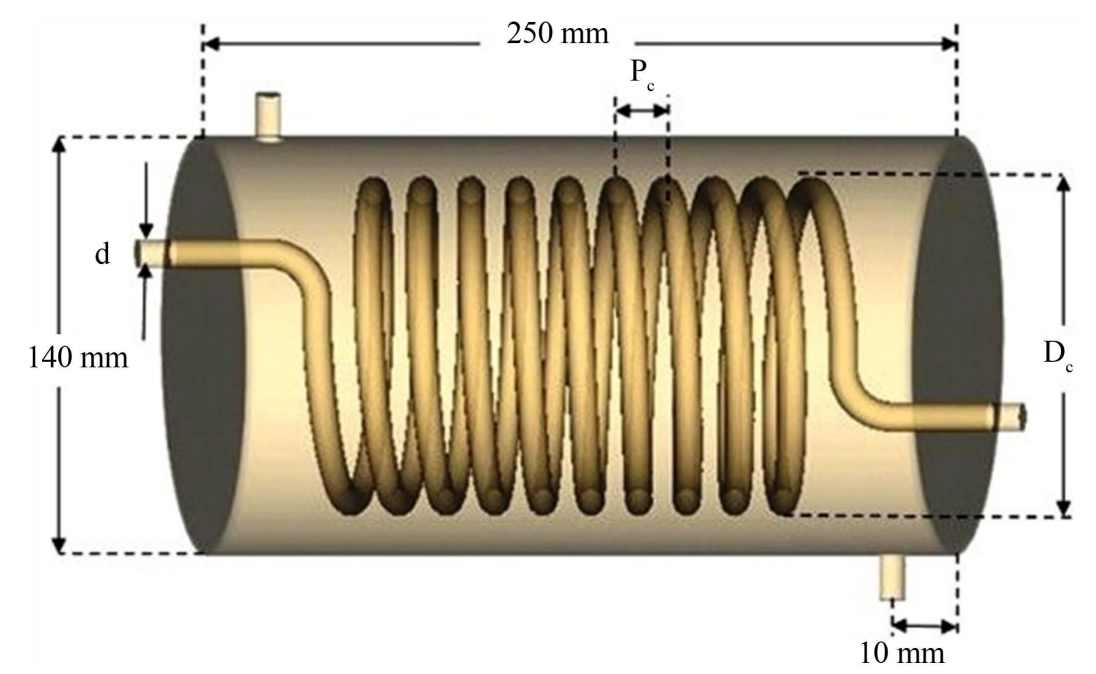

Figure 2. Shell and tube helical coil heat exchanger. Source: [23]. 


\subsection{Helical Coil Heat Exchanger Overview}

According to researchers, HCHE are broadly used in heating and cooling applications such as heat recovery system, food industries, nuclear power plant, chemical processing, solar water heater, and refrigeration and air-conditioning units [16] [26]-[32]. [33] reported that the HCHE showed increase in the heat transfer rate, effectiveness and overall heat transfer coefficient over the straight tube heat exchanger on all mass flow rates and operating conditions. Heat transfer enhancement is one of the key issues of energy saving and compact designs [34].

[35] reported higher temperature drop for helical coil tube when compared to straight tube heat exchanger due to the curvature effect of the helical coil. [36] reported the use of HCHE in falling film evaporator for energy saving by recycling the heat from vapour due to larger surface area in a small volume and are therefore used for applications with small temperature difference or high volumetric heat rating [24]. [37] reported the use of HCHE in heat recovery from exhaust gases using refrigerant R134a and R245fa and showed that refrigerants are better than water as a thermal fluid. HCHE offers distinct advantages, such as improved thermal efficiency, compactness, easy maintenance and lower installed cost [3].

[16] reported that HCHE had advantages over conditions of low flow rates or laminar flow unlike a typical shell-and-tube exchanger which exhibited low heat-transfer coefficients at low flow rate thus becoming uneconomical especially, when there exists low pressure in one of the fluids, usually from accumulated pressure drops in other process equipment. However, when an application requires equipment suitable for high operating pressure and/or extreme temperature gradients, a helical coil unit should be considered [3]. Cleaning of helical coils for these multiple-phase fluids can prove to be more difficult than shell and tube counterpart; however the helical coil unit would require cleaning less often [38]. Hence, the main disadvantages of HCHE are that they cannot be cleaned easily and are therefore not suitable for crystallization type of applications [24].

\section{Mass and Heat Transfer in Helical Coil Heat Exchanger}

Heat transfer on HCHE depends largely on the coil size, tube size, mass flow rate, type of thermal fluids and number of turns [39]. Studies involving helical coils and heat exchange have focused on two major boundary conditions, namely 1) constant wall temperature and 2) constant heat flux [32] [40]. [41] considered natural convection boundary condition for HCHE outer surface while modelling the performance of two HCHE placed into the storage tank. They reported that heat transfer rate through the coil depends on 1) inner coil convection process 2) outer coil convection process 3 ) the conduction through the tube wall and 4) the fouling resistances on the inner and outer HCHE surfaces.

Heat transfers in the HCHE can be analyzed by force convection [42] [43] [44] [45], natural convection [32] and mixed convection [46]. Mixed convection, 
simply is a combination of forced and free convections. According to [47], mixed convection flow is determined simultaneously by both an outer forcing system (the outer energy supply to the fluid system) and inner volumetric or mass forces (which is the non-uniform density distribution of a fluid medium in a gravity field). [48] analyzed the variation in the temperature drop, heat transfer rate and pressure when the numbers of turns in a double tube helical coil heat exchanger are changed. From the study, they showed that:

1) As the number of turn increases, the temperature drops of hot fluid also increased.

2) The increase in number of turns resulted in higher rate of heat transfer.

3) Temperature at the outlet of hot fluid was found to be more at the location far from the coil axis as compared to nearer location.

4) As the number of turn increases, the absolute pressure inside the coil also increased, and it was maximum at inlet section of outer cold fluid.

5) The pressure at the inlet and outer fluid was maximum at the point far from the coil axis.

According to [48], double tube HCHE offers certain advantages over the straight tubes shell and tube type heat exchanger, in terms of better heat transfer and mass transfer coefficients due to its fluid dynamics inside the pipe of double tube HCHE.

[49] presented a comparative analysis of the different correlations given by the different researchers for HCHE and established the overall effect of these parameters on Nusselt numbers and heat transfer coefficient. The analysis showed that helical coils were efficient in low Reynolds numbers. Also, at constant coil diameter $(D)$, increase in the tube diameter $(d)$ increased the curvature ratio $(\delta)$, which led to the increase in the intensity of secondary flow developed in fluid flow. The increase in the intensity of secondary flow developed in fluid flow increased the Nusselt numbers. Hence, it was desirable to have small coil diameter $(D)$ and large tube diameter $(d)$ in helical coil heat exchanger, for large intensities of secondary flow in tube.

[33] reviewed on forced convection through HCHE. In the review, it was found that forced convection fluid motion took place by external force so that the fluid velocity was high and heat transfer coefficient was high. The results showed that HCHE showed increase in the heat transfer rate, effectiveness and overall heat transfer coefficient over the straight tube heat exchanger on all mass flow rates and operating conditions as also confirmed by [50].

The computational fluid dynamics (CFD) simulation was carried out to study the variation of coil diameter of HCHE with mass flow rate of water at inlet temperature of $332 \mathrm{~K}$ [51]. In the study, temperature drop, heat transfer rate, heat transfer coefficient and Nusselt number were compared with the geometric variations and variation in mass flow rate. Results showed that the temperature drop decreased for decreased in coil diameter and increased in mass flow rate whereas heat transfer rate increased with increase in coil diameter and mass flow rate. 
[52] investigated heat transfer and fluid flow characteristics for both Newtonian and non-Newtonian fluids in tube-in-tube helical coil (TTHC) heat exchangers numerically with and without baffles in both parallel and counter flows. The results showed that the frictional and Nusselt number is higher in the TTHC heat exchanger with baffles in the annulus compared to the TTHC heat exchanger without baffles. Also, the TTHC heat exchanger with baffles had significant influence on heat transfer at low Prandtl number whereas at high Prandtl number, the flow configuration had high significance in heat transfer.

[53] studied helical coiled double pipe heat exchanger for counter flow. Characteristics of the fluid flow were also studied for the constant temperature and constant wall heat flux conditions. From the results, Nusselt number increased with increase in curvature ratio. Also, the value of Nusselt number was found to increase with increase in mass flow rate (i.e. inlet velocity). With increase in the ratio of coil diameter to tube diameter $(D / d)$, (inverse of curvature ratio), the Nusselt number and frictional factor decreased for a particular value of Reynolds number $(R e)$. Nusselt number and frictional factor had maximum value for $D / d$ $=10$ and minimum value for $D / d=30$.

[54] studied the effect of increase in inner coil flow rate for a constant flow rate in the annulus region for double pipe $\mathrm{HCHE}$ and observed that the overall heat transfer coefficient increased with increase in inner coil flow rate for a constant flow rate in the annulus region. Also, different characteristics were observed for different flow rates in the annulus region for a constant flow rates in the inner-coiled tube. Also, three-dimensional analysis was used to study the heat transfer characteristics of a double-tube HCHE using nanofluids under laminar flow conditions by [55]. The results showed that for $2 \% \mathrm{CuO}$ nanoparticles in water and at the same mass flow rate in inner tube and annulus, the heat transfer rate of the nanofluid was approximately $14 \%$ greater than of pure water. The results also showed that the convective heat transfer coefficients of the nanofluids and water increased with increase in the mass flow rate and the Dean number.

[56] analyzed the heat transfer and pressure drop of conical coil heat exchanger with various tube diameters, fluid flow rates and cone angles with hot and cold water of flow rate 10 to 100 liters per minute (Re range 500 to 5000) and 30 to 90 per minute respectively. The temperatures and pressure drop across the heat exchanger were recorded at different mass flow rates of cold and hot fluid. The various parameters (heat transfer coefficient $(h)$, Nusselt number $(\mathrm{Nu})$ effectiveness $(\varepsilon)$ and friction factor $(f)$ ) were estimated using the temperature, mass flow rate and pressure drop across the heat exchanger. The analysis indicated that, $\mathrm{Nu}$ and $\mathrm{f}$ is function of flow rate, tube diameter, coil angle, and curvature ratio. Increased in tube side flow rate increased $\mathrm{Nu}$, whereas it reduced with increase in shell side flow rate. Increased in coil angle and tube diameter, reduced $\mathrm{Nu}$.

[29] worked on mixed convection heat transfer in vertical HCHE with various Reynolds numbers and Rayleigh numbers and various tube to coil diameter ra- 
tios and different coil pitch. The effect of tube diameter, coil pitch, shell-side and tube-side mass flow rate was assessed over the performance coefficient and modified effectiveness of vertical HCHE in both laminar and turbulent flow inside coil. The result showed effective axial temperature profiles of heat exchanger on the mass flow rate of tube-side to shell-side ratio. Also, the $\mathcal{E}-\mathrm{NTU}$ model relation of the mixed convection heat exchangers was the same compared to that of a pure counter-flow heat exchanger.

[57] designed the heat exchanger for maximum values of the flow rates at the tube and shell side respectively. The maximum heat transfer of $41 \mathrm{~kW}$ with the pinch point temperature difference was fixed at $10 \mathrm{~K}$. In this study, the hot side inlet temperature of the water was $95^{\circ} \mathrm{C}$, while the cold side was an organic fluid, $\mathrm{R}-404 \mathrm{~A}$ refrigerant circulated with an inlet temperature of $27^{\circ} \mathrm{C}$, resulting in a pinch point temperature difference at the outlet of the heat exchanger of $10^{\circ} \mathrm{C}$. The mass flow rates of both fluids were fixed at $2.5 \mathrm{~kg} / \mathrm{s}$ and $0.25 \mathrm{~kg} / \mathrm{s}$ at the hot and cold side respectively. The results showed that, at higher mass flow rate of the organic fluid, increase in heat transfer in the HCHE was achieved.

Comparing the results from the measurements with the designed specifications gave an enhanced heat transfer of $\sim 10 \%$. Moreover, from the thermal match analysis, a pinch point temperature difference of only $2^{\circ} \mathrm{C}$ was reached at the exit of the heat exchanger, which is lower than the designed value of $10 \mathrm{~K}$. From the arguments mentioned in this work, [57] concluded that a more accurate design of the heat exchanger with appropriate correlations could lead to increase in heat transfer and the cycle efficiency, and hence, a new and more accurate correlation for an optimal design of this heat exchanger needs to be derived.

\section{Effectiveness of Helical Coil Heat Exchanger}

The effectiveness of heat exchangers is the ratio actual heat transferred to the heat that could be transferred by heat exchanger of indefinite size, and this can be achieved when the heat transfer power is increased or when the pressure losses generated is reduced. [58] reported that the effectiveness of heat exchangers depends on the convection heat transfer coefficient of the fluid. [59] studied the effectiveness of helical coil and straight tube heat exchangers by varying the inlet temperature of the hot water. From the results, it was found that the HCHE had better effectiveness than straight tube heat exchanger for all the inlet temperatures of water. Also, [59] confirmed that the effectiveness of HCHE is found to be higher for all the inlet hot water temperatures when compared to that of the straight tube heat exchanger.

[60] also vary parameters like number of coils, flow rate and temperature to study the effectiveness of a heat exchanger. The results showed that the heat transfer was higher for both parallel and counter flow in HCHE as compared with the straight tube heat exchanger. However, [61] compared the effectiveness of helical coil and straight tube heat exchanger, using mass flow rate of hot water and cold water in both parallel and counter flow configuration. The study showed that, the effectiveness increased with increase in cold water mass flow 
rate for constant hot water mass flow rate and vice versa for both helical coil and straight tube heat exchangers with parallel and counter flow configuration. But, HCHE counter flow was more effective in all these conditions than the straight tube parallel flow heat exchanger.

[4] concluded that HCHE was seen to increase the heat transfer coefficient compared to a similarly dimensioned straight tube heat exchanger. The improvement of thermal conductivity of based fluid with addition of nano particles increased the effectiveness of HCHE [62] and maximum effectiveness was obtained for $\mathrm{CuO} /$ water nanofluid. The determination of convective heat transfer coefficient in both helical and straight tubular heat exchangers under turbulent flow conditions was experimented by [63] using HCHE with coils of two different curvature ratios $(d / D=0.114$ and 0.078$)$, and in straight tubular heat exchangers at various flow rates $\left(1.89 \times 10^{-4}-6.31 \times 10^{-4} \mathrm{~m}^{3} / \mathrm{s}\right)$ and for different end-point temperatures $\left(92^{\circ} \mathrm{C}-149^{\circ} \mathrm{C}\right)$. The results showed that the overall heat transfer coefficient $(U)$ in the HCHE is much higher than that in straight tubular heat exchangers. In addition, $U$ was found to be larger in the coil of larger curvature ratio $(d / D=0.114)$ than in the coil of smaller curvature ratio $(d / D=$ 0.078).

[64] experimentally investigated the condensation heat transfer of R-134a in horizontal straight and helically coiled tube-in-tube heat exchangers. The experiments were carried out at three saturation temperatures $\left(350,400\right.$ and $\left.450^{\circ} \mathrm{F}\right)$ with the refrigerant mass flux varying from $100 \mathrm{~kg} / \mathrm{m}^{2} \cdot \mathrm{s}$ to $400 \mathrm{~kg} / \mathrm{m}^{2} \cdot \mathrm{s}$ and the vapour quality ranging from 0.1 to 0.8 . The effects of vapour quality and mass flux of R-134a on the condensation heat transfer coefficient were investigated. The results indicate that the condensation heat transfer coefficients of the helical section were $4 \%-13.8 \%$ higher than that of the straight section.

[65] has applied the efficiency and effectiveness method and has obtained promising results. These results are why the efficiency and effectiveness method is used in a relatively complex and without similar problem or conflicting interest.

\section{Conclusion}

From the review, HCHE provided more excellent heat transfer performance and effectiveness than straight tubes and others heat exchangers. The secondary flow development inside the helical tube led to improvement in heat transfer rates. The effectiveness of HCHE was found to be higher when compared to that of the straight tube heat exchanger for all the inlet temperatures and on all mass flow rates and operating conditions. Heat transfer coefficient increased with increase in the curvature ratio of HCHE for the same flow rates. The mean heat transfer coefficient distribution for laminar flow in coiled tubes is uniform and that of turbulent flow around the tube perimeter is essentially non-uniform. The nonuniformity is caused by the non-homogeneity of the flow velocity and temperature distributions which can cause heat transfer from the inner to the outer ge- 
neratrix. Thermal fluids played a predominant role in mass and heat transfer in special applications such as heat recovery system, heat removal system and heat enhancement.

\section{Acknowledgements}

The authors thanked the authority of University of Uyo and the Department of Chemical and Petroleum Engineering for the opportunity to carry out this work.

\section{Conflicts of Interest}

The authors declare no conflicts of interest regarding the publication of this paper.

\section{References}

[1] Shah, R.K. and Sekulic, D.P. (2003) Classification of Heat Exchanger. In: Shah, R.K. and Sekulic, D.P., (Eds.), Fundamentals of Heat Exchanger Design, John Wiley \& Sons Inc., Hoboken, $941 \mathrm{p}$.

[2] Ismael, O.M., Rai, A.K., Mahdi, H.F. and Sachan, V. (2014) An Experimental Study of Heat Transfer in a Plate Heat. Exchanger International Journal of Advanced Research in Engineering and Technology (IJARET), 5, 31-37.

[3] Lines, J.R. (2021) Helically Coiled Heat Exchangers Offers Advantages. Bulletin HHE-30, 5 p. https://www.graham-mfg.com/usr/pdf/TechLibHeatTransfer/14.PDF

[4] Borse, D. and Bute, J.V. (2018) A Review on Helical Coil Heat Exchanger. International Journal for Research in Applied Science \& Engineering Technology, 6, 492-497. https://doi.org/10.22214/ijraset.2018.2070

[5] Fsadni, A.M and Whitty, J.P.M. (2016) A Review on the Two-Phase Heat Transfer Characteristics in Helically Coiled Tube Heat Exchangers. International Journal of Heat and Mass Transfer, 95, 551-565.

https://doi.org/10.1016/j.ijheatmasstransfer.2015.12.034

[6] Narrein, K. and Mohammed, H.A. (2013) Influence of Nanofluids and Rotation on Helically Coiled Tube Heat Exchanger Performance. Thermochimica Acta, 564, 13-23. https://doi.org/10.1016/j.tca.2013.04.004

[7] Berger, S.A., Talbot, L. and Yao, L.S. (1983) Flow in Curved Pipes. Annual Review of Fluid Mechanics, 15, 461-512.

https://doi.org/10.1146/annurev.fl.15.010183.002333

[8] Bai, B.F., Guo, L.J., Feng, Z.P. and Chen, X.J. (1999) Turbulent Heat Transfer in a Horizontally Coiled Tube. Heat Transfer-Asian Research, 28, 395-403. https://doi.org/10.1002/(SICI)1523-1496(1999)28:5\%3C395::AID-HTJ5\%3E3.0.CO; $\underline{2-\mathrm{Y}}$

[9] Futagami, K. and Aoyama, Y. (1988) Laminar Heat Transfer in Helically Coiled Tubes. International Journal of Heat and Mass Transfer, 31, 387-396. https://doi.org/10.1016/0017-9310(88)90021-X

[10] Xin, R.C., Awwad, A., Dong, Z.F. and Ebadian, M.A. (1996) An Investigation and Comparative Study of the Pressure Drop in Air-Water Two-Phase Flow in Vertical Helicoidal Pipes. International Journal of Heat and Mass Transfer, 39, 735-743. https://doi.org/10.1016/0017-9310(95)00164-6

[11] Jayakumar, J.S., Mahajani, S.M., Mandal, J.C., Vijayan, P.K. and Bhoi, R. (2008) Experimental and CFD Estimation of Heat Transfer in Helically Coiled Heat Ex- 
changers. Chemical Engineering Research and Design, 86, 221-232. https://doi.org/10.1016/j.cherd.2007.10.021

[12] Li, Y.X, Wu, J.H, Wang, H., Kou, L.P. and Tian, X.H. (2012) Fluid Flow and Heat Transfer Characteristics in Helical Tubes Cooperating with Spiral Corrugation. Energy Procedia, 17, 791-800. https://doi.org/10.1016/j.egypro.2012.02.172

[13] Vishvakarma, S., Kumbhare, S. and Thakur, K.K. (2016) A Review on Heat Transfer through Helical Coil Heat Exchangers. International Journal of Engineering Sciences and Research Technology, 5, 607-612.

[14] Kováts, P., Velten, C., Mansour, M., Thévenin, D. and Zähringer, K. (2020) Mixing Characterization in Different Helically Coiled Configurations by Laser-Induced Fluorescence. Experiments in Fluids, 61, Article No. 203.

https://doi.org/10.1007/s00348-020-03035-0

[15] Prabhanjan, D.G. (2000) Influence of Coil Characteristic on Heat Transfer to Newtonian Fluids. Faculty of Graduate Studies and Research of McGill University, McGill University, Montréal.

[16] Naphon, P. (2007) Thermal Performance and Pressure Drop of the Helical-Coil Heat Exchangers with and without Helically Crimped Fins. International Communication of Heat Mass Transfer, 34, 321-330. https://doi.org/10.1016/j.icheatmasstransfer.2006.11.009

[17] Naphon, P. and Suwagrai, J. (2007) Effect of Curvature Ratios on the Heat Transfer and Flow Developments in the Horizontal Spirally Coiled Tubes. International Journal of Heat and Mass Transfer, 50, 444-451. https://doi.org/10.1016/j.ijheatmasstransfer.2006.08.002

[18] Jayakumar, J.S., Mahajani, S.M., Mandal, J.C., Iyer, K.N. and Vijayan, P.K. (2010) CFD Analysis of Single-Phase Flows inside Helically Coiled Tubes. Computers and Chemical Engineering, 34, 430-446. https://doi.org/10.1016/j.compchemeng.2009.11.008

[19] Salimpour, M.R. (2009) Heat Transfer Coefficients of Shell and Coiled Tube Heat Exchangers. Experimental Thermal and Fluid Science, 33, 203-207. https://doi.org/10.1016/j.expthermflusci.2008.07.015

[20] Ruffell, A.E. (2021) Flow and Pressure Drop in Coiled Tube. Thermopedia. https://www.thermopedia.com/content/639/

[21] Kumar, V., Gupta, P. and Nigam, K.D.P. (2007) Fluid Flow and Heat Transfer in Curved Tubes with Temperature-Dependent Properties. Industrial and Engineering Chemistry Research, 46, 3226-3236. https://doi.org/10.1021/ie0608399

[22] Kuzma-Kichta, Y.A. (2021) Heat Transfer in Coiled Tubes. Thermopedia. https://www.thermopedia.com/content/640/

[23] Jamshidi, N., Farhadi, M., Ganji, D.D. and Sedighi, K. (2012) Experimental Analysis of Heat Transfer Enhancement in Shell and Helical Tube Heat Exchangers. Applied Thermal Engineering, 51, 644-652.

https://doi.org/10.1016/j.applthermaleng.2012.10.008

[24] Jayanti, S. (2021) Helical Coils Boilers. A-to-Z Guide to Thermodynamics, Heat and Mass Transfer and Fluids Engineering. Thermopedia.

https://www.thermopedia.com/content/845/

[25] Reddy, K.V.K., Kumar, B.S.P., Gugulothu, R., Anuja, K. and Rao, P.V. (2017) CFD Analysis of a Helically Coiled Tube in Tube Heat Exchanger. Materials Today: Proceedings, 4, 2341-2349. https://doi.org/10.1016/j.matpr.2017.02.083

[26] Andrzejczyk, R. and Muszynski, T. (2016) Performance Analyses of Helical Coil 
Heat Exchangers. The Effect of External Coil Surface Modification on Heat Exchanger Effectiveness. Archives of Thermodynamics, 37, 137-159.

[27] AlHajeri, H.M., Almutairi, A., Al-Hajeri, M.A., Alenezi, A., ALajmi, R. and Koluib, A.M. (2020) Condensation Heat Transfer of R-407C in Helical Coiled Tube Heat Exchanger. Processes, 8, Article No. 1157. https://doi.org/10.3390/pr8091157

[28] Ali, A.A., Kumaragurubaran, B., Suresh, S. and Babu, K.L. (2015) Heat Transfer Enhancement in Vertical Helical Coiled Heat Exchanger by Using Nanofluid $\mathrm{TiO}_{2} /$ Water. International Research Journal of Engineering and Technology (IRJET), 2, 2480-2484.

[29] Ghorbani, N., Taherian, H., Mirgolbabaei, H. and Gorji, M. (2010) Experimental Study of Mixed Convection Heat Transfer in Vertical Helically Coiled Heat Exchanger. Experimental Thermal and Fluid Science, 34, 900-905.

https://doi.org/10.1016/j.expthermflusci.2010.02.004

[30] Janssen, L.A.M. and Hoogendoorn, C.J. (1978) Laminar Convective Heat Transfer in Helical Coiled Tubes. International Journal of Heat and Mass Transfer, 21, 1197-1206. https://doi.org/10.1016/0017-9310(78)90138-2

[31] Kumar, P.C.M. and Chandrasekar. M. (2019) CFD Analysis on Heat and Flow Characteristics of Double Helically Coiled Tube Heat Exchanger Handling MWCNT/Water Nanofluids. Heliyon, 5, e02030. https://doi.org/10.1016/j.heliyon.2019.e02030

[32] Prabhanjan, D.G., Rennie, T.J., and Raghavan, G.S.V. (2004) Natural Convective Heat Transfer from Helical Coiled Tubes. International Journal of Thermal Sciences, 43, 359-365. https://doi.org/10.1016/j.ijthermalsci.2003.08.005

[33] Battu, S. and Sridev, V. (2016) A Brief Review on Forced Convection through Helical Coil Heat Exchangers. International Journal for Innovative Research in Science \& Technology, 2, 178-181.

[34] Rai, N and Hegde, R.N. (2016) Investigations on Heat Transfer Enhancement in Helical Coil Heat Exchanger Using CuO Nanofluid. National Conference on Advances in Mechanical Engineering Science, 52-55.

[35] Karmankar, R.G. (2015) Enhancement of Heat Transfer Coefficient through Helical Coil. International Research Journal of Engineering and Technology (IRJET), 2, 2125-2129.

[36] Wei, J. (2017) Helical-Coil Heat Exchanger Application in Falling Film Evaporator for Energy Saving. Cornerstone: A Collection of Scholarly and Creative Works for Minnesota State University, Mankato.

https://cornerstone.lib.mnsu.edu/cgi/viewcontent.cgi? article=1727\&context=etds

[37] Bonafoni, G and Capata, R. (2015) Proposed Design Procedure of a Helical Coil Heat Exchanger for an Orc Energy Recovery System for Vehicular Application. Mechanics, Materials Science \& Engineering Journal, 1, 72-96.

[38] Lizheng Stainless Steel Tube \& Coil Corp (2015) Helical Coil Heat Exchanger Design.

https://www.lizhengcoils.com/single-post/2015/08/20/Helical-Coil-Heat-Exchanger -Design

[39] Sikandar, M.U. (2019) Design of Helical Coil Heat Exchanger for a Mini Power Plant. International Journal of Scientific \& Engineering Research, 10, 303-313.

[40] Nandakumar, K. and Masliyah, J.H. (1982), Bifurcation in Steady Laminar Flow through Curved Tubes. Journal of Fluid Mechanics, 119, 475-490. https://doi.org/10.1017/S002211208200144X

[41] Fernandez-Seara, J., Piniro-Pontevedra, C. and Dopazo, J.A. (2014) On the Performance 
of a Vertical Helical Coil Heat Exchanger. Numerical Model and Experimental Validation. Applied Thermal Engineering, 62, 680-689.

https://doi.org/10.1016/j.applthermaleng.2013.09.054

[42] Banka, H., Reddy, V.V. and Radhika, M. (2016) CFD Analysis of Shell and Tube heat Exchanger Using Titanium Carbide, Titanium Nitride and Zinc Oxide Nanofluid. International Journal of Innovations in Engineering and Technology, 315-322.

[43] Mirgolbabaei, H. and Taherian, H. (2010) Laminar Forced Convection Heat Transfer in Helical Coiled Tube Heat Exchangers. Thermal Sciences, 1-13.

[44] Kumar, P.C.M. and Palanisamy, K. (2017) A Review of Forced Convection Heat Transfer and Pressure Drop in Shell and Helical Coiled Tube Heat Exchanger of Nanofluids. International Journal of Research and Scientific Innovation (IJRSI), 4, 26-34.

[45] Safari, A., Saffar-Avval, M. and Amani, E. (2018) Numerical Investigation of Turbulent Forced Convection Flow of Nano Fluid in Curved and Helical Pipe Using Four-Equation Model. Powder Technology, 328, 47-53.

https://doi.org/10.1016/j.powtec.2018.01.025

[46] Ghorbani, N., Taherian, H., Mirgolbabaei, H. and Gorji, M. (2010) An Experimental Study of Thermal Performance of Shell-and-Coil Heat Exchangers. International Communications in Heat and Mass Transfer, 37, 775-781.

https://doi.org/10.1016/j.icheatmasstransfer.2010.02.001

[47] Polijakov, A.F. (2011) Mixed Convection. Thermopedia ${ }^{\mathrm{TM}}, \mathrm{A}-\mathrm{Z}$ Guide to Thermodynamics. Heat \& Mass Transfer, and Fluid Engineering. Thermopedia.

http://www.thermopedia.com/content/957

[48] Dradhomar, P., Verma, S., Singh, V., Dradhomar, P. and Manjunatha, M. (2017) CFD Analysis of Double Tube Helical Coil Heat Exchanger for Different Heat Transfer Characteristics. International Journal of Advanced Research, 5, 1752-1757. https://doi.org/10.21474/IJAR01/4006

[49] Purandare, P., Lele, M.M. and Gupta, R.K. (2012) Parametric Analysis of Helical Coil Heat Exchanger. International Journal of Engineering Research and Technology, 1, 1-5.

[50] Murugapandi, D., Surendra, P., Parthiban. S., Kumar M.P. and Gopinath, S. (2018) Heat Transfer Enhancement Using Helical Coil Heat Exchanger. International Journal of Engineering Research and Technology (IJERT), 6, 1-6.

[51] Nilay, A., Gupta, V. and Bagri, S. (2017) Performance Analysis of Helical Coil Heat Exchanger Using Numerical Technique. International Journal of Scientific Research in Science, Engineering and Technology, 3, 152-156.

[52] Kushwaha, N., Kumawat, T.C., Nigam, K.D.P. and Kumar, V. (2020) Heat Transfer and Fluid Flow Characteristics for Newtonian and Non-Newtonian Fluids in a Tube-in-Tube Helical Coil Heat Exchanger. Industrial Engineering Chemistry Research, 59, 3972-3984. https://doi.org/10.1021/acs.iecr.9b07044

[53] Mishra, T.N. (2015) Modeling and CFD Analysis of Tube in Tube Helical Coil Heat Exchanger. International Journal of Science and Research (IJSR), 4, 1536-1541.

[54] Holkar, G.P., Khanwalkar, P.M. and Korane, A.B. (2016) A Review on Numerical Modeling of a Double Pipe Helical Heat Exchanger. International Journal on Theoretical and Applied Research in Mechanical Engineering (IJTARME), 5, 66-72.

[55] Huminic, G. and Huminic, A. (2011) Heat Transfer Characteristics in Double Tube Helical Heat Exchangers Using Nanofluids. International Journal of Heat and Mass Transfer, 54, 4280-4287. https://doi.org/10.1016/j.ijheatmasstransfer.2011.05.017

[56] Purandare, P., Lele, M.M. and Gupta, R.K. (2016) Experimental Investigation on 
Heat Transfer and Pressure Drop of Conical Coil Heat Exchanger. Thermal Sciences, 20, 2086-2099.

[57] Lazova, M., Huisseune, H., Kaya, A., Lecompte, S., Kosmadakis, G. and De Paepe, M.D. (2016) Performance Evaluation of a Helical Coil Heat Exchanger Working under Supercritical Conditions in a Solar Organic Rankine Cycle Installation. Energies, 9, Article No. 432. https://doi.org/10.3390/en9060432

[58] Hasanuzzamana, M., Saidura, R. and Rahim, N.A. (2011) Effectiveness Enhancement of Heat Exchanger by Using Nanofluids. 2011 IEEE First Conference on Clean Energy and Technology (CET), Kuala Lumpur, 27-29 June 2011, 98-103. https://doi.org/10.1109/CET.2011.6041444

[59] Sreejith, K., Sreesastha, R.T.R., Varghese, J.A., Francis, M., Mossas, V.J., Nidhin, M.J., Nithil, E.S. and Sushmitha, S. (2015) Experimental Investigation of a Helical Coil Heat Exchanger. International Journal of Engineering and Science, 5, 1-5.

[60] Chinna, B., Ankanna, B. and Reddy, S. (2014) Performance Analysis of Fabricated Helical Coil Heat Exchanger. International Journal of Engineering Research, 3, 33-39.

[61] Kharat, R., Bhardwaj, N. and Jha, R.S. (2009) Development of Heat Transfer Coefficient Correlation for Concentric Helical Coil Heat Exchanger. International Journal of Thermal Sciences, 48, 2300-2308.

https://doi.org/10.1016/j.ijthermalsci.2009.04.008

[62] Srinivas, T. and Vinod, A.V. (2016) Heat Transfer Intensification in a Shell and Helical Coil Heat Exchanger Using Water-Based Nanofluids. Chemical Engineering and Processing. Process Intensification, 102, 1-8.

https://doi.org/10.1016/j.cep.2016.01.005

[63] Coronel, P and Sandeep, K.P. (2008) Heat Transfer Coefficient in Helical Heat Exchangers under Turbulent Flow Conditions. International Journal for Food Engineering, 4, 12 p. https://doi.org/10.2202/1556-3758.1209

[64] Chen, M., Kim, I.X., Sun, X., Christensen, R.N., Skavdahl, I., Utgikar, V. and Sabharwall, P. (2014) Preliminary Design of a Helical Coil Heat Exchanger for a Fluoride Salt-Cooled High-Temperature Test Reactor. Transactions of the American Nuclear Society, 111, 1460-1463.

[65] Nogueira, É. (2021) Efficiency and Effectiveness Thermal Analysis of the Shell and Helical Coil Tube Heat Exchanger Used in an Aqueous Solution of Ammonium Nitrate Solubility (ANSOL) with $20 \% \mathrm{H}_{2} \mathrm{O}$ and $80 \%$ AN. Journal of Materials Science and Chemical Engineering, 9, 24-45. https://doi.org/10.4236/msce.2021.96003 


\section{Abbreviations, Acronyms, and Symbols}

\begin{tabular}{|c|c|c|}
\hline $\mathrm{C}$ & - & Celsius \\
\hline CFD & - & Computational fluid dynamics \\
\hline $\mathrm{CuO}$ & - & Copper oxide \\
\hline$D$ & - & Coil diameter $(\mathrm{m})$ \\
\hline$D_{\text {coil }}$ & - & Coil diameter $(\mathrm{m})$ \\
\hline$d$ & - & Tube diameter (m) \\
\hline$f$ & - & Friction factor \\
\hline $\mathrm{F}$ & - & Fahrenheit \\
\hline$h$ & - & Heat transfer coefficient \\
\hline $\mathrm{HCHE}$ & - & Helical coil heat exchanger \\
\hline $\mathrm{K}$ & - & Kelvin \\
\hline $\mathrm{k}$ & - & Kilo \\
\hline$k$ & - & Turbulence kinetic energy \\
\hline $\mathrm{kg}$ & - & Kilograms \\
\hline$L$ & - & Diameter for pipes \\
\hline $\mathrm{m}$ & - & Meters \\
\hline $\mathrm{mm}$ & - & Millimetres \\
\hline$N u$ & - & Nusselt number (-) \\
\hline NUT & - & Number of Transfer Unit \\
\hline$\%$ & - & Percentage \\
\hline$P_{c}$ & - & Coil pitch \\
\hline $\operatorname{Pr}$ & - & Prandtl number $(-)$ \\
\hline$R$ & - & Refrigerant \\
\hline $\operatorname{Re}$ & - & Reynolds number (-) \\
\hline s & - & Seconds \\
\hline SST & - & Shear Stress Transport \\
\hline TTHC & - & Tube-in-tube helical coil \\
\hline$U$ & - & Overall heat transfer coefficient \\
\hline $\mathrm{W}$ & - & Watts \\
\hline \multicolumn{3}{|c|}{ Greek Letters } \\
\hline$\alpha$ & - & Convective heat transfer coefficient \\
\hline$\varepsilon$ & - & Effectiveness \\
\hline$\lambda$ & - & Thermal conductivity \\
\hline$\delta$ & - & Curvature ratio (-) \\
\hline \multicolumn{3}{|c|}{ Superscripts } \\
\hline 。 & - & Degree \\
\hline
\end{tabular}

